University of Nebraska - Lincoln

DigitalCommons@University of Nebraska - Lincoln

Stephen DiMagno Papers

Published Research - Department of Chemistry

$11-2010$

\title{
Fluoride-promoted ligand exchange in diaryliodonium salts
}

\author{
Bijia Wang \\ University of Nebraska-Lincoln \\ Ronald Cerny \\ University of Nebraska-Lincoln, rcerny1@unl.edu \\ ShriHarsha Uppaluri \\ University of Nebraska-Lincoln \\ Jayson J. Kempinger \\ University of Nebraska-Lincoln \\ Stephen G. DiMagno \\ University of Nebraska-Lincoln, sdimagno@uic.edu
}

Follow this and additional works at: https://digitalcommons.unl.edu/chemistrydimagno

Part of the Chemistry Commons

Wang, Bijia; Cerny, Ronald; Uppaluri, ShriHarsha; Kempinger, Jayson J.; and DiMagno, Stephen G., "Fluoride-promoted ligand exchange in diaryliodonium salts" (2010). Stephen DiMagno Papers. 3. https://digitalcommons.unl.edu/chemistrydimagno/3

This Article is brought to you for free and open access by the Published Research - Department of Chemistry at DigitalCommons@University of Nebraska - Lincoln. It has been accepted for inclusion in Stephen DiMagno Papers by an authorized administrator of DigitalCommons@University of Nebraska - Lincoln. 


\title{
Fluoride-promoted ligand exchange in diaryliodonium salts
}

\author{
Bijia Wang, Ronald L. Cerny, ShriHarsha Uppaluri, \\ Jayson J. Kempinger, and Stephen G. DiMagno \\ Department of Chemistry and Nebraska Center for Materials and Nanoscience, \\ University of Nebraska-Lincoln, Lincoln, NE 68588-0304, USA \\ Corresponding author - S. G. DiMagno, tel 402 472-9895, fax 402 472-9402, email sdimagno1@unl.edu
}

\begin{abstract}
Diaryliodonium salts are shown to undergo rapid, fluoride-promoted aryl exchange reactions at room temperature in acetonitrile. Aryl exchange is shown to be exquisitely sensitive to the concentration of fluoride ion in solution; fast exchange is observed as the fluoride concentration approaches a stoichiometric amount at $50 \mathrm{mM}$ substrate concentration. The reaction is slowed, but not halted if benzene is the solvent, indicating that free fluoride ion or a four-coordinate anionic I(III) species may be responsible for the exchange. The fluoride-promoted aryl exchange reaction is general and allows direct measurement of the relative stabilities of diaryliodonium salts featuring different aryl substituents. The aryl exchange reaction may be of practical use for the preparation of hitherto inaccessible diaryliodonium salts, thus it also has implications for labeling radiotracers for molecular imaging with ${ }^{18} \mathrm{~F}$-fluoride $\left(t_{1 / 2}=109.7 \mathrm{~min}\right)$.
\end{abstract}

Keywords: Diaryliodonium salts, Fluorination, Ligand exchange, PET, ${ }^{18} \mathrm{~F}$, Aryl fluorides, Reductive elimination

\section{Introduction}

Positron emission tomography using ${ }^{18} \mathrm{~F}$-labeled radiotracers is a valuable clinical research and diagnostic technique for human or animal organ imaging. Although $\left[{ }^{18} \mathrm{~F}\right]-2-d e-$ oxy-2-fluoro-D-glucose is currently the most widely used ${ }^{18} \mathrm{~F}$ fluorinated radiotracer [1-3], a main focus of recent efforts in radiotracer synthesis has been the preparation of $\left[{ }^{18} \mathrm{~F}\right]$-fluorinated aromatic compounds [4-10]. Since the initial report from Pike in 1995 [11], the radiofluorination of diaryliodonium salts has garnered attention as a potential methodology for late stage introduction of fluorine into diverse aromatic substrates. This methodology complements typical $\mathrm{S}_{\mathrm{N}}$ Ar-based approaches by providing a means to fluorinate electron-rich, as well as problematic electron-poor aromatic rings not easily accessed by direct substitution (Figure 1).

To date, electronic substituent effects have provided the best means to control regioselectivity in diaryliodonium salt decomposition. It is generally observed that if an unsymmetrically substituted diaryliodonium salt undergoes thermal decomposition with ${ }^{18} \mathrm{~F}$-fluoride ion, it is the electron-poor ring that is fluorinated selectively. During the course of our work with diaryliodonium salts we observed this trend in regioselectivity, however, we were also struck by the fact that regioselectivity was not strongly correlated with the electronic character of the two rings. For example, the diaryliodonium salt 1, which features an electron-rich 4-methoxyphenyl substituent paired with a relatively electron-poor aryl substituent, gave surprisingly poor regioselectivity (Figure 2). Also of interest was that the regioselectivity became increasingly worse as the reaction progressed. The observation of the surprisingly better regioselectivity for fluorination of $\mathbf{2}$, and the intriguing time course of the regioselectivity of $\mathbf{1}$ led us to investigate in detail the reaction of fluoride ion with diaryliodonium salts. These studies led us to discover a remarkably facile, fluoridepromoted aryl ligand exchange reaction of these compounds.

Aryl transfer from organometallic reagents (Sn, $\mathrm{Si}, \mathrm{B}, \mathrm{Hg}$, and $\mathrm{Li}$ ) [12-20] to monoaryliodine(III) species is commonly used to prepare diaryliodine(III) compounds. These compounds, in turn, are used as arylating regents to transfer aryl ligands to organic or inorganic nucleophiles directly $[5,21-$ 29], or in combination with transition metal catalysis [30-34]. The exchange of aryl ligands on I(III) centers is in line with the general tendency of these compounds to engage in reactions typical of organometallic complexes. Though it has not previously been observed directly, exchange of aryl ligands among I(III) centers in diaryliodonium salts has been posited in a few studies. Reutov et al. observed isotope exchange between diaryliodonium tetrafluoroborates and [ $\left.{ }^{131} \mathrm{I}\right]$-labeled aryl iodides at the melting temperatures of the salts [35]. Reich and Cooperman have shown that 5-aryl-3,7-dimethyl-5H-dibenziodoles (Figure 3) exhibit temperature-dependent NMR spectra [36]. At low temperatures, two methyl groups appear as singlets at $\delta 2.24$ and $2.41 \mathrm{ppm}$, which coalesce as the temperature is raised. The line shape changes are reversible and consistent with degenerate thermal isomerization of the aryl ligand about 

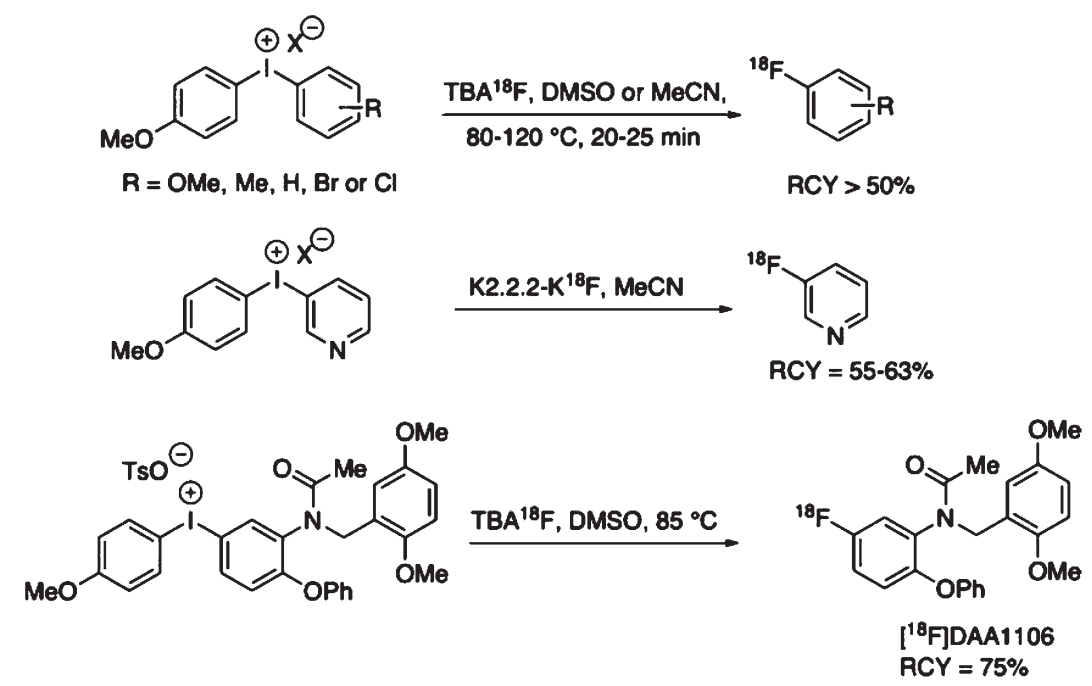

Figure 1. Examples of radiofluorination using diaryliodonium salts $[5,11,42]$. RCY is the decay-corrected radiochemical yield.

T-shaped iodine. The observation of large negative entropies of activation and irreproducible rate constants for the isomerization was interpreted as evidence for an intermolecular ligand exchange isomerization mechanism (Figure 3). Although previous reports have suggested aryl ligand exchange in these compounds, here we show for the first time that mildly basic ligands, such as fluoride, promote facile aryl swapping among diaryliodine(III) species at room temperature.

\section{Results and discussion}

Compounds 1-9 (Figure 4) were prepared by established methods [16, 37-39]. Treatment of the symmetrical diaryliodonium hexafluorophosphates $\mathbf{3}\left(\mathbf{P F}_{6}\right)$ and $\mathbf{4}\left(\mathbf{P F}_{6}\right)$ with tetramethylammonium fluoride (TMAF) in $\mathrm{CD}_{3} \mathrm{CN}$ gave rise to ion exchange to the corresponding fluoride salts, 3(F) and 4(F), as was evidenced by the appearance of a broad singlet in the downfield region of the ${ }^{19} \mathrm{~F}$ NMR spectra $(\delta=-17.9 \mathrm{ppm}$ for 3(F), $\delta=-13.0$ ppm for $4(F))$ and a concomitant sharpening of the signals for the $\mathrm{PF}_{6}$ anion at $\delta=-72.8 \mathrm{ppm}$. A general upfield shift of the signals in the aromatic region was also<smiles>COc1ccc([I-](c2ccccc2)c2ccccc2)cc1</smiles><smiles>COc1ccc([Bi](c2ccc(F)cc2)c2ccc(OC)c(OC)c2)cc1</smiles><smiles>COc1ccc(F)cc1</smiles><smiles>COc1ccc(F)cc1</smiles>

Figure 2. Observed regioselectivity for $\mathbf{1}\left(\mathbf{P F}_{6}\right)$ (featuring the relatively electron-poor phenyl substituent) is worse than that of $\mathbf{2}\left(\mathbf{P F}_{6}\right)$ (featuring relatively electron-rich 3,4-dimethoxyphenyl group): (a) TMAF/ $\mathrm{CH}_{3} \mathrm{CN}$, evaporation of solvent, addition of $\mathrm{d}_{6}$-benzene, filtration; (b) $140{ }^{\circ} \mathrm{C}, 15 \mathrm{~min}$. noted in the ${ }^{1} \mathrm{H}$ NMR spectrum (Figure 5). In contrast, treatment of the unsymmetrically substituted diaryliodonium salt $\mathbf{1}\left(\mathbf{P F}_{6}\right)$ with TMAF under the same conditions led to a complex change in the spectrum (Figure 5) and an apparent increase in the number of signals in the aromatic region. Several potential explanations for this increase in complexity were considered (Scheme 1), including (1) formation of fluoride bridged syn and anti dimers, (2) the generation of T-shaped diastereomers with different aryl groups occupying the axial positions, or (3) fast, fluoride-promoted aryl ligand exchange resulting in formation of three distinct diaryliodonium salts.

To test whether the addition of fluoride ion promoted the formation of bridged dimers, the fluoride salt obtained by treatment of $\mathbf{1}\left(\mathbf{P F}_{6}\right)$ with TMAF was further treated with TMS triflate to generate the I(III) triflates and to remove the fluoride in the form of TMSF. Even after all traces of fluoride were removed, the ${ }^{1} \mathrm{H}$ NMR spectrum remained complex and distinct from that of an independently synthesized 1(OTf). Thus, the formation of dimers as a possible origin of the observed spectral complexity could be excluded. To examine whether the addition of fluoride had promoted formation of two different T-shaped diastereomers, we independently synthesized 1(OTf), 3(OTf), and 4(OTf) and subjected them to ES-MS analysis. The pure salt $\mathbf{1}(\mathrm{OTf})$ gave a single, clean cation peak of $m / z=310.7$ ( $\mathbf{M}^{+}$(-OTf)). Similarly, 3(OTf) and 4(OTf) gave cation peaks of $m / z=340.7$ and 280.7, respectively, indicating that these three compounds did not undergo any exchange reactions during the electrospray ionization process in the mass spectrometer. In contrast, a preparation of the triflate salt of 1(OTf) that had been exposed previously to fluoride ion gave three cation peaks of $m / z=280.7,310.7$, and 340.7, indicating the presence of three distinct diaryliodonium salts (Figure 6). MS-MS analysis of each of these ions indicated that the principal decomposition product was the corresponding biphenyl formed by extrusion of iodine. The ES-MS data are consistent with the formation of three different diaryliodonium compounds upon treatment of unsymmetrical diaryliodonium salts with fluoride in solution, and definitively exclude formation of different $\mathrm{T}$-shaped diastereomers as a possible origin of the complexity observed by NMR spectroscopy. All data support a remarkably rapid, fluoride-promoted aryl exchange reaction for unsymmetrically substituted diaryliodonium salts, and the presence of an equilibrated mixture of three distinct diaryliodonium fluorides in solution.

We performed a series of control reactions to rule out other potential origins of the observed aryl exchange reaction. Though the crystallinity of the $\mathrm{PF}_{6}$ salts is particularly attrac- 


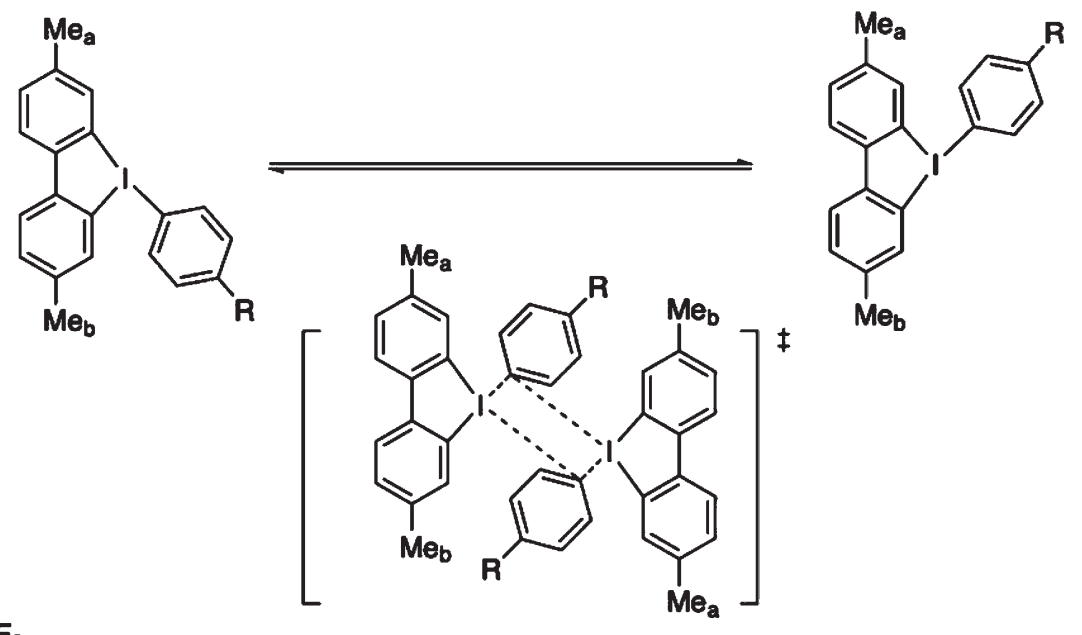

\section{$\mathrm{R}=\mathrm{H}, \mathrm{CF}_{3}$}

Figure 3. Exchange in 5-aryl-3,7-dimethyl-5H-dibenziodoles showing the postulated dimeric transition state [36].

tive from a synthetic point of view, diaryliodonium hexafluorophosphates are never used in radiochemistry studies because their tendency to liberate ${ }^{19} \mathrm{~F}$-fluoride ion at high temperature results in isotopic dilution. To investigate whether counterion decomposition was playing a role in the observed exchange reaction, we investigated the stability of $\mathbf{1}\left(\mathbf{P F}_{6}\right), \mathbf{3}\left(\mathbf{P F}_{6}\right)$ and $\mathbf{4}\left(\mathbf{P F}_{6}\right)$ in $\mathrm{CD}_{3} \mathrm{CN}$. No changes in the NMR spectra of these compounds were observed, even after the samples were heated at $80^{\circ} \mathrm{C}$ for $24 \mathrm{~h}$. The triflate salts $\mathbf{1 ( O T f )}$, 3(OTf), and 4(OTf) were also unchanged upon heating in $\mathrm{CD}_{3} \mathrm{CN}$. Treatment of $\mathbf{1 ( O T f )}$ with 1 equiv. of TMAF in $\mathrm{CD}_{3} \mathrm{CN}$ also led to rapid exchange of the aryl ligands, indicating that the weakly coordinating $\mathrm{PF}_{6}$ and OTf anions behave similarly under these conditions. Finally, to probe whether TMSOTf played a role in the exchange reaction, $\mathbf{1}\left(\mathbf{P F}_{6}\right)$ was treated with tetramethylammonium acetate in $\mathrm{CD}_{3} \mathrm{CN}$. Clean ion exchange to $\mathbf{1}(\mathrm{OAc})$ was observed and the ${ }^{1} \mathrm{H}$ NMR spectrum (Figure 7) was consistent with a sin- gle unsymmetrically substituted diaryliodonium salt in solution. Treatment of $\mathbf{1}(\mathrm{OAc})$ with TMSOTf yielded TMSOAc and 1(OTf). The ${ }^{1} \mathrm{H}$ NMR spectrum (Figure 7) and ES-MS data of 1(OTf) prepared in this manner were identical to those derived from an independently prepared sample. All of the control experiments are consistent with the view that added fluoride promotes the observed exchange of the aryl ligands on I(III).

Despite the existence of three separate diaryliodonium fluorides in solution, the ${ }^{19} \mathrm{~F}$ NMR spectrum of $\mathbf{1 ( F )}$ in $\mathrm{CD}_{3} \mathrm{CN}$ displays one broad singlet at $-12.3 \mathrm{ppm}$. This observation is consistent with fast exchange of fluoride among the three I(III) species. We sought to slow the exchange rate by removing excess salts, switching to a nonpolar solvent ( $\mathrm{d}_{8}$-toluene) and lowering the temperature, but under no circumstances could we reach the coalescence temperature for the exchange. Representative low temperature $\left(-35,-60\right.$, and $\left.-80{ }^{\circ} \mathrm{C}\right){ }^{19} \mathrm{~F} N M R$ spectra are shown in Figure 8.<smiles>[X][Te]c1ccc(OC)cc1</smiles>

1<smiles>[X]C(=[O+])c1ccccc1</smiles>

4<smiles></smiles>
$X=\mathrm{PF}_{6}, \mathrm{OTf}, \mathrm{F}$<smiles>[CH-][I-](c1ccc(OC)cc1)c1ccc(OC)c(OC)c1</smiles>

2<smiles>[X][Te](c1ccc(OC)cc1)c1cccc(C(F)(F)F)c1</smiles><smiles>[Z][Te](c1ccc(OC)cc1)c1cc(C)ccc1C</smiles><smiles>[C][Si](c1ccc(OC)cc1)c1ccc(OC)cc1</smiles>

3<smiles>[X][Te](c1ccc(OC)cc1)c1cccc(C#N)c1</smiles><smiles>[X][Te]c1ccc(Br)cc1</smiles>

Figure 4. Diaryliodonium salts discussed in the work. Throughout the text, the particular counterion of interest $\left(\mathrm{X}=\mathrm{PF}_{6}, \mathrm{OTf}, \mathrm{F}\right)$ is denoted in parentheses following the compound number (i.e. $\mathbf{1}\left(\mathbf{P F}_{6}\right)$ ). 


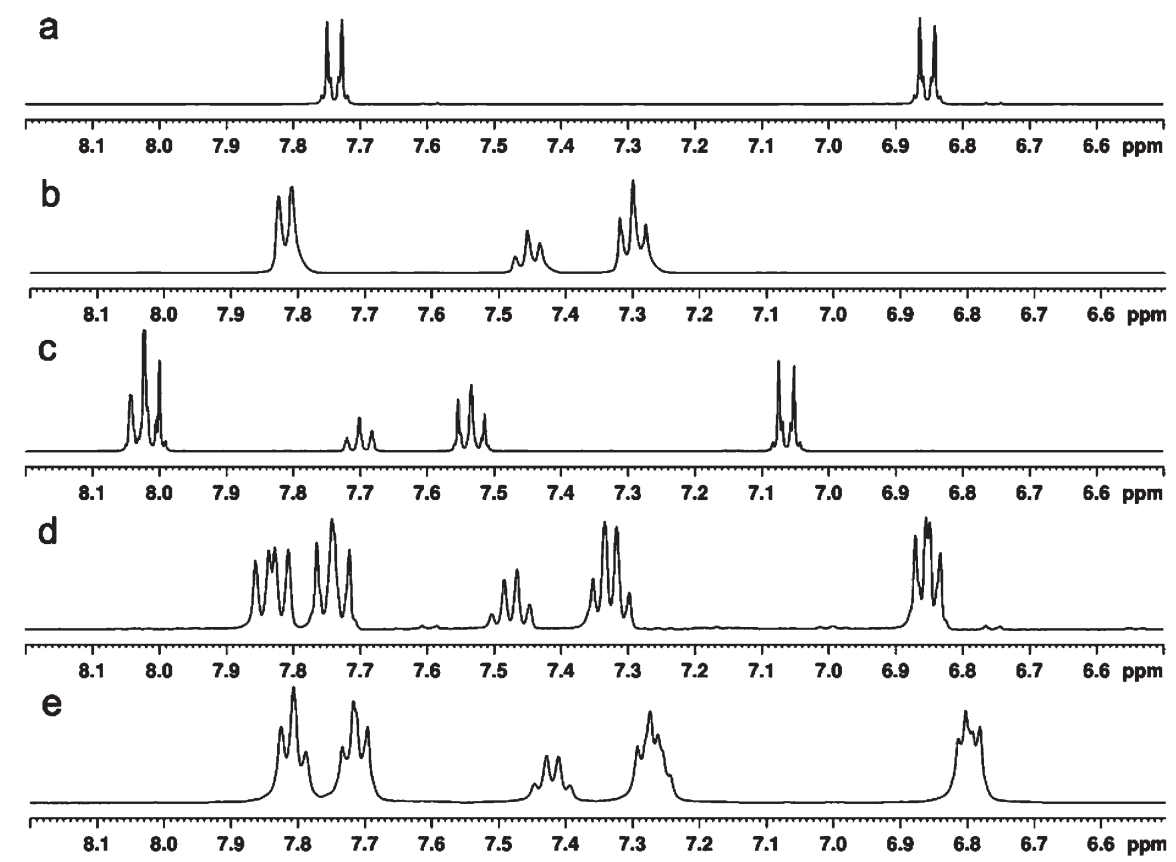

Figure 5. ${ }^{1} \mathrm{H}$ NMR spectra in $\mathrm{CD}_{3} \mathrm{CN}$ of (a) $\mathbf{3}(\mathrm{F}),(\mathrm{b}) \mathbf{4}(\mathrm{F}),(\mathrm{c}) \mathbf{1}\left(\mathrm{PF}_{6}\right),(\mathrm{d}) \mathbf{1}\left(\mathbf{P F}_{6}\right)$ after it was treated with TMAF in $\mathrm{CH}_{3} \mathrm{CN}$, desalted with benzene, and dissolved in $\mathrm{CD}_{3} \mathrm{CN}$, and (e) a mixture of $3(\mathrm{~F})$ and $4(\mathrm{~F})$ in $\mathrm{CD}_{3} \mathrm{CN}$. Only the aromatic regions are displayed for clarity.

Since radiotracer synthesis using diaryliodonium salts is typically conducted with nanograms of fluoride ion and a million-fold excess of potential substrate, we decided to probe the rate of the aryl exchange process as a function of fluoride ion concentration. As was seen above, adding 1 equiv. of TMAF to a solution containing $\mathbf{1}\left(\mathbf{P F}_{6}\right)$ in dry $\mathrm{CD}_{3} \mathrm{CN}$ allowed the aryl exchange reaction to reach equilibrium before the first ${ }^{1} \mathrm{H}$ NMR data could be obtained (approximately $8 \mathrm{~min}$ ). This rapid equilibration implies a first order rate constant for the process of at least $1.2 \times 10^{-3} \mathrm{~s}^{-1}$. (The simple kinetic model used to determine this rate constant is $-\mathrm{d}\left[\mathrm{Ar}^{1}-\mathrm{I}-\mathrm{Ar}^{2}\right] / \mathrm{dt}=$ $k\left(\left[\mathrm{Ar}^{1}-\mathrm{I}-\mathrm{Ar}^{2}\right]-\left[\mathrm{Ar}^{1}-\mathrm{I}-\mathrm{Ar}^{2}\right]_{\mathrm{eq}}\right)$ where $\left[\mathrm{Ar}^{1}-\mathrm{I}-\mathrm{Ar}^{2}\right]_{\mathrm{eq}}$ is the concentration of the remaining heterogeneously substituted diaryliodonium salt once an equilibrium has been established.) In contrast, when the TMAF concentration was only halved, aryl exchange became so slow $\left(t_{1 / 2}>24 \mathrm{~h}\right)$ that the rate could not be determined accurately since it was on the same timescale as room temperature decomposition processes. With 0.89 equiv. of added TMAF, the reaction rate was in an intermediate range convenient for performing a kinetic study by ${ }^{1} \mathrm{H}$ NMR spectroscopy.

Figure 9 shows a set of stacked ${ }^{1} \mathrm{H}$ NMR spectra taken over the initial $160 \mathrm{~min}$ for the reaction of $\mathbf{1}\left(\mathbf{P F}_{\mathbf{6}}\right)$ and 0.89 equiv. of
TMAF in dry acetonitrile. (The reaction reached equilibrium in 8 h.) A first order plot $\left(\ln \left[\mathrm{Ar}^{1}-\mathrm{I}-\mathrm{Ar}^{2}\right] /\left[\mathrm{Ar}^{1}-\mathrm{I}-\mathrm{Ar}^{2}\right]_{\mathrm{eq}}\right.$ vs. $\left.t\right)$ of these data yielded a rate constant of $1.15 \times 10^{-4} \mathrm{~s}^{-1}$. In a similar study with an only slightly reduced amount of added TMAF (0.81 equiv., a 9\% decrement in $\left[\mathrm{F}^{-}\right]$) the equilibration rate dropped tenfold; the observed rate constant was $1.06 \times 10^{-5}$ $\mathrm{s}^{-1}$. These observations suggest that the majority of the fluoride remains bound to the I(III) center and that a small amount of dissociated fluoride or an anionic difluorodiaryl I(III) species is responsible for catalyzing the aryl exchange process. With a substoichiometric amount of added fluoride, the concentration of dissociated "free" fluoride is low, leading to a drastic decrease in the rate of aryl group exchange. These results also suggest that fluoride-promoted aryl exchange may not be a significant concern under the conditions used typically for PET radiotracer synthesis where fluoride ion concentration is very low, and also that this catalyzed exchange reaction could have synthetic potential.

Recently we found that the fluorination of diaryliodonium salts could be improved substantially if nonpolar solvents were used during the thermal decomposition step. Additionally, we found that the presence of excess salts, even seemingly benign salts such as TMAOTf or $\mathrm{TMAPF}_{6}$, could

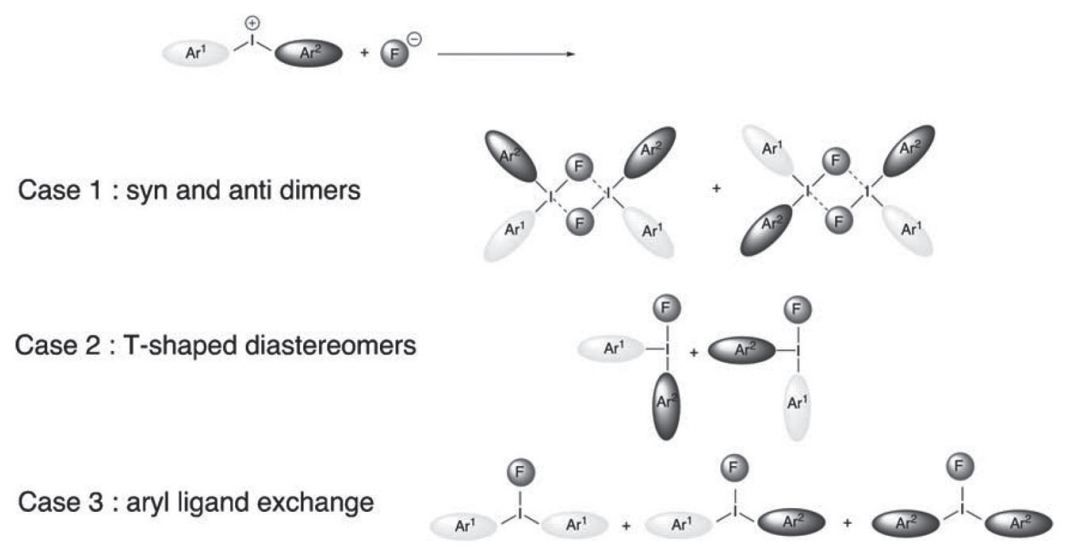

Scheme 1. Possible origins of the additional complexity observed in the ${ }^{1} \mathrm{H}$ NMR spectrum of $\mathbf{1}\left(\mathbf{P F}_{6}\right)$ after addition of fluoride. 


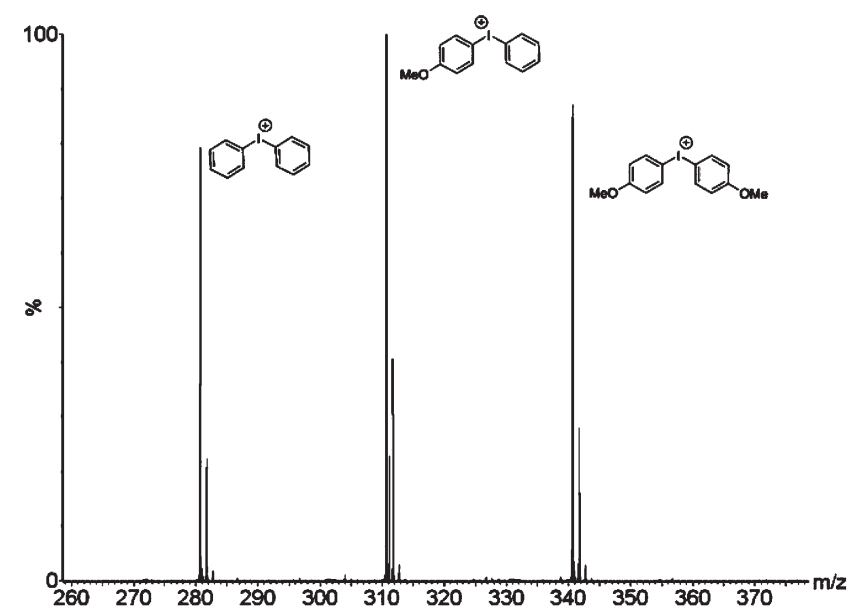

Figure 6. ES-MS spectrum of $\mathbf{1 ( O T f )}$ after it had been treated with TMAF followed by TMSOTf.

have a profound and negative impact upon the amount of fluoroarene produced during this reaction. The mechanism by which excess salt promotes deleterious side reactions remains obscure, but a reasonable hypothesis is that these additional ions serve to balance charge during ligand exchange reactions, and that ligand exchange reactions are related to the formation of I(III) species of differing redox potentials. Accordingly, we investigated whether excess salt, namely the tetraalkylammonium hexafluorophosphate formed from the ion exchange reaction, facilitated the aryl ligand exchange process. We precipitated and isolated $\mathbf{3}(\mathbf{F})$ by treating $\mathbf{3}\left(\mathbf{P F}_{6}\right)$ with TBAF in THF. ${ }^{1} \mathrm{H}$ and ${ }^{19} \mathrm{~F}$ NMR analyses indicated that no TBAPF 6 remained in the sample after this desalting procedure. Compound $4(\mathbf{F})$ was desalted by a similar procedure. When 3(F) was mixed with 1 equiv. of $4(F)$ in acetonitrile, an aryl exchange reaction ensued which reached equilibrium in less than 10 min (Figure 5, panel e). Since one full equivalent of fluoride was present and tetraalkylammonium $\mathrm{PF}_{6}$ was not, this experiment indicates that the fluoride ion concentration is a much more important determinant of the aryl exchange rate than the concen-

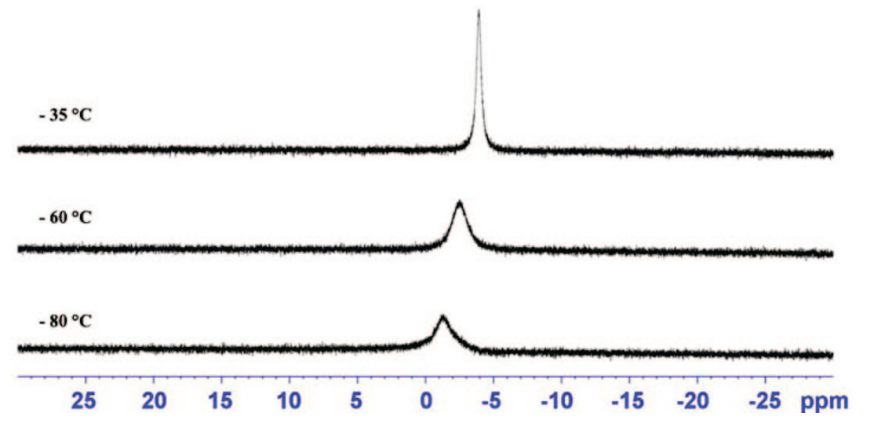

Figure $8 .{ }^{19} \mathrm{~F}$ NMR spectra of a mixture of $\mathbf{1}(\mathrm{F}), \mathbf{3 ( F )}$ and $\mathbf{4}(\mathrm{F})$ in $\mathrm{d}_{8}$-toluene at various temperatures.

tration of spectator salts. Similarly, when 1 equiv. of $\mathbf{3 ( F )}$ was mixed with 1 equiv. of $\mathbf{4}\left(\mathbf{P F}_{6}\right)$ in $\mathrm{CD}_{3} \mathrm{CN}$ solution (to give a total of 0.5 equiv. of fluoride ion), aryl exchange did not proceed to an observable extent within $24 \mathrm{~h}$. These results support the conclusion that added tetraalkylammonium salts of weakly coordinating anions do not play a significant role in the aryl exchange reactions of diaryliodonium salts in $\mathrm{CD}_{3} \mathrm{CN}$.

To investigate the propensity of aryl ligand exchange to occur under the high temperature conditions used for aromatic fluorination, we examined the thermal decomposition of diaryliodonium salts in the presence of substoichiometric amounts of TMAF in $\mathrm{d}_{6}$-benzene at $80{ }^{\circ} \mathrm{C}$. In a typical experiment $0.05 \mathrm{mmol}$ of $\mathbf{1}\left(\mathbf{P F}_{6}\right)$ was dissolved in $0.3 \mathrm{~mL}$ of dry acetonitrile and $0.025 \mathrm{mmol}$ of anhydrous TMAF in $0.3 \mathrm{~mL}$ acetonitrile was introduced. The solvent was removed under reduced pressure, dry $d_{6}$-benzene was added to the remaining salts, and the mixture was shaken and filtered into an NMR tube equipped with a screw top PTFE closure. ${ }^{1} \mathrm{H}$ and ${ }^{19} \mathrm{~F}$ NMR revealed that very little, if any aryl exchange occurred during the sample preparation procedure. The sample was heated to $80{ }^{\circ} \mathrm{C}$, and the reaction progress was monitored by NMR spectroscopy. At this temperature both reductive elimination and aryl exchange were evident. During the course of the reaction only three decomposition products were formed: fluorobenzene, iodobenzene and iodoanisole. Importantly, the amount of fluorobenzene formed equaled the sum of the amounts of

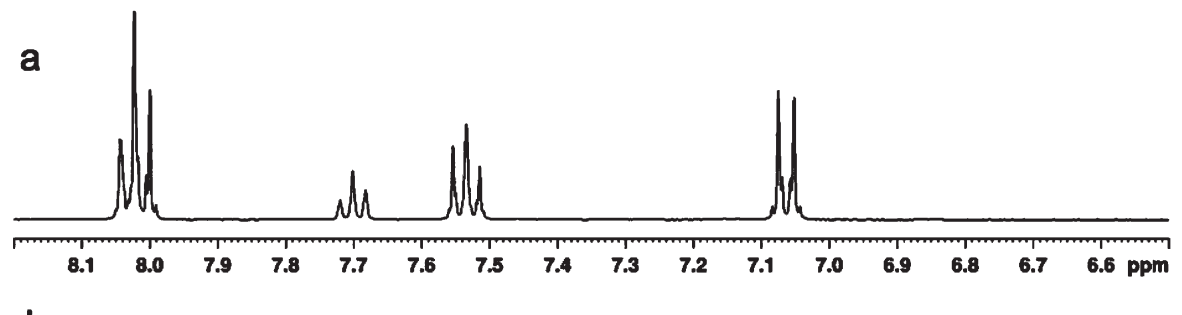

b

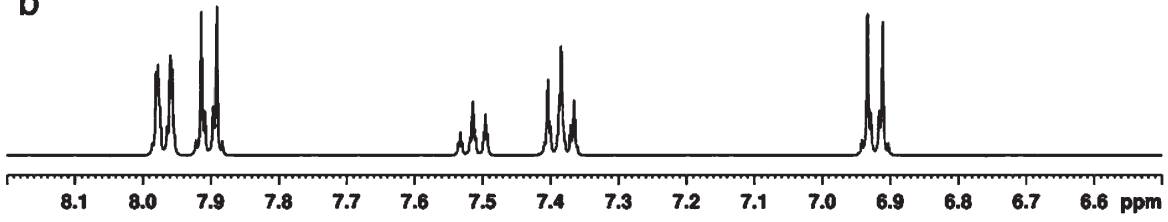

C

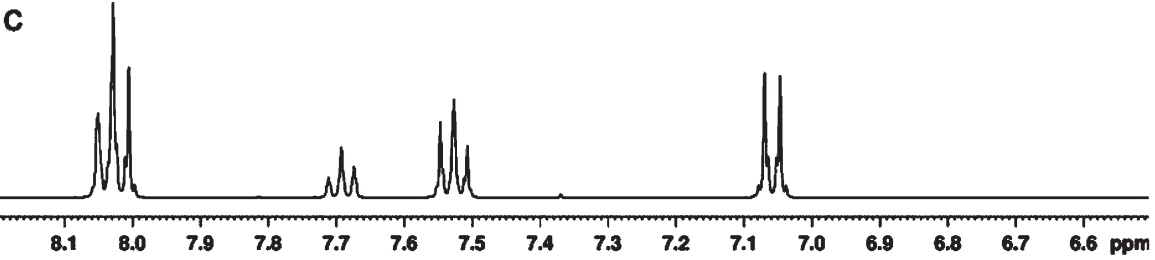

Figure 7. Changes observed in the ${ }^{1} \mathrm{H}$ NMR spectrum of $\mathbf{1}\left(\mathbf{P F}_{6}\right)$ upon treatment with TMAOAc followed by TMSOTf in CD $\mathrm{CN}$ : (a) $\mathbf{1}\left(\mathbf{P F}_{6}\right)$, (b) $\mathbf{1}(\mathrm{OAc})$, and (c) 1(OTf). The expanded aromatic regions of the spectra are shown for clarity. 


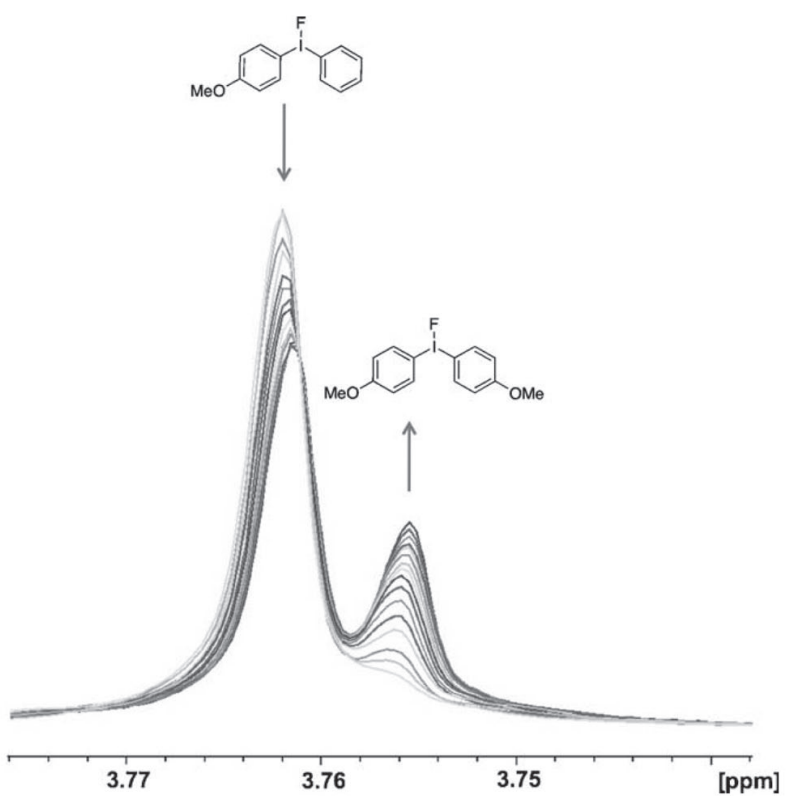

Figure 9. Stacked ${ }^{1} \mathrm{H}$ NMR spectra (detail showing the p-methoxy region) of $\mathbf{1}\left(\mathbf{P F}_{6}\right)$ and 0.89 equiv. of TMAF. Elapsed time $=160 \mathrm{~min}$.

iodobenzene and 4-iodoanisole that formed. This observation indicates that fluorination of benzene occurred by reductive elimination reactions of two different phenyl-substituted iodonium salts (Figure 10).

It is noteworthy that the regioselectivity for fluorobenzene formation was perfect; no 4-fluoroanisole was formed under these substoichiometric conditions ( 0.5 equiv. of fluoride). Instead, the symmetrical diaryliodonium salt $3\left(\mathbf{P F}_{6}\right)$ accumulated during the course of the reaction. (An independently prepared sample of $\mathbf{3}\left(\mathbf{P F}_{6}\right)$ treated 0.5 equiv. of TMAF could only be coaxed to undergo reductive elimination at appreciable rates at temperatures significantly higher than $80^{\circ} \mathrm{C}$.) The highly selective formation of fluorobenzene observed in this case contrasts dramatically with the results obtained when a full equivalent of fluoride was used (Figure 2). Under stoichiometric conditions at $140{ }^{\circ} \mathrm{C}$, a relatively large amount of 4-fluoroanisole was generated. In addition, the time course of the reaction $\mathbf{1}\left(\mathbf{P F}_{6}\right)$ with 1 equiv. of TMAF showed exceptionally high selectivity for fluorobenzene formation at low conversion, and only at a much longer reaction time did 4-fluoroanisole begin to appear. This study makes it clear that aryl exchange and thermal decomposition are in competition at 80 ${ }^{\circ} \mathrm{C}$ in benzene, even when substoichiometric amounts of fluoride are present in solution. If fluoride is still present when no phenyl-substituted diaryliodonium salts remain, $3(\mathrm{~F})$ begins to decompose to 4-fluoroanisole, albeit at an appreciably slower rate than fluorobenzene is formed. Thus, the true "directing group abilities" of aryl substituents in diaryliodonium salt fluorination reactions can only be determined when the fluoride is present at low concentration and the reaction is monitored to determine which aryl iodides and which salts are generated during the course of the functionalization process. Alternatively, the true ability of aryl ligands on I(III) to direct regioselective functionalization can be assessed using other nucleophiles that do not promote aryl ligand exchange. Such nucleophiles include soft, relatively nonbasic anions such as azide or thiophenoxide [40].

It seems clear from these data that fluoride-promoted aryl exchange reactions may not play an important role in the preparation of $\left[{ }^{18} \mathrm{~F}\right]$-labeled radiotracers because the miniscule amount of ${ }^{18} \mathrm{~F}$-fluoride added is unlikely to promote aryl ligand exchange. However, fluoride is not the only anion capable of promoting aryl swapping in diaryliodonium species; we have found that other hard bases, including hydroxide, ethoxide, and phenoxide also promote aryl exchange reactions of diaryliodonium salts. For example, when an acetonitrile solution of $\mathbf{1}\left(\mathbf{P F}_{6}\right)$ was treated with sodium trifluoroethoxide at room temperature, an immediate ligand exchange reaction occurred. Because of the increased reactivity of trifluoroethoxide compared to fluoride, formation of phenyl trifluoroethyl ether was observed (with excellent selectivity) even at room temperature. As the reaction progressed, iodobenzene and 4-iodoanisole were produced and the symmetrical salt $3\left(\mathrm{OCH}_{2} \mathrm{CF}_{3}\right)$ accumulated. Only after most of the phenyl-substituted diaryliodonium salts were reduced did 4-(2-trifluoroethoxy)anisole begin to form. These results mirror exactly the observations seen for the thermal decomposition of $\mathbf{1}(\mathbf{F})$ at higher temperature. The alkoxide promoted exchange process may be responsible, in part, for the fact that hydrolysis reactions of unsymmetrical diaryliodonium salts are reported to be insensitive to electronic effects [41]. With these observations in mind, it is reasonable to consider that use of hydroxide and carbonate bases in the preparation of ${ }^{18} \mathrm{~F}$-fluoride may give rise to aryl exchange reactions of diaryliodonium salts during radiochemical syntheses; thus they should be avoided. Assessments of the "directing group abilities" of electron-rich arenes may be compromised under such conditions.

The fluoride-promoted aryl exchange reaction provides a mechanism by which the relative solution stabilities of various diaryliodonium salts can be interrogated directly for the first time. Inspection of Table 1, which lists the relative populations of symmetrically and unsymmetrically substituted diaryliodonium salts at equilibrium in benzene, indicates that the unsymmetrically substituted diaryliodonium salt becomes increasingly more stable as the electronic disparity between the two rings increases. If two relatively electron-rich rings are bonded to an I(III) center, as in $\mathbf{2 ( F )}$, the observed distribution is simply statistical at equilibrium in the absence of competing

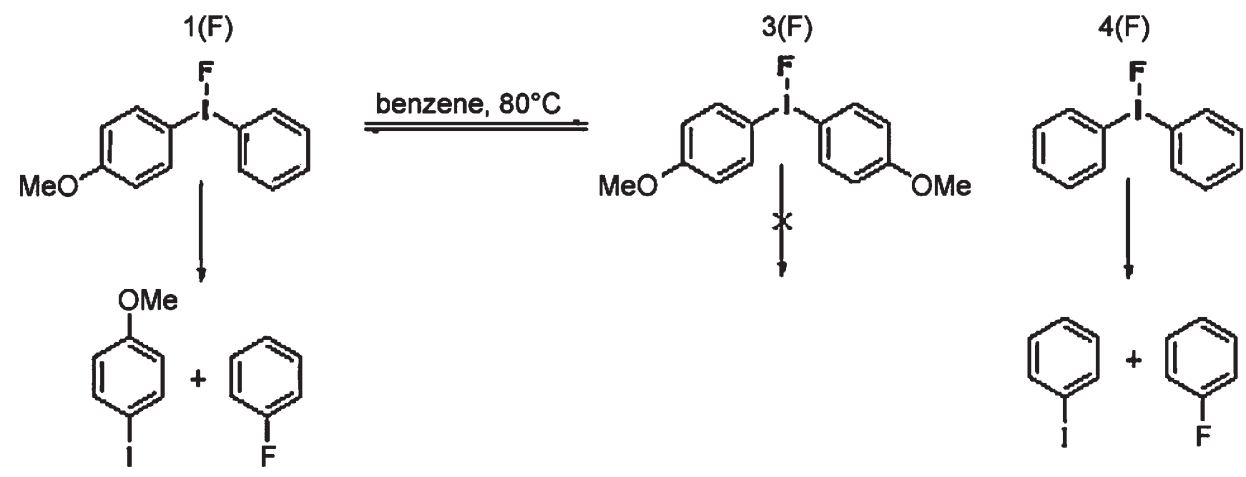

Figure 10. Mechanism for the generation of 4-iodobenzene during the thermal decomposition of 1(F). 
Table 1. Equilibrium populations of symmetrically and unsymmetrically substituted diaryliodonium fluorides. ${ }^{*}$

\begin{tabular}{llll}
\hline$\#$ & $\mathbf{A r}^{\mathbf{1}}-\mathbf{I}-\mathbf{A r}^{\mathbf{2}} \mathbf{( \% )}$ & $\mathbf{A r}^{\mathbf{1}}-\mathbf{I}-\mathbf{A r}^{\mathbf{1}} \mathbf{( \% )}$ & $\mathbf{A r}^{\mathbf{2}}-\mathbf{I}-\mathbf{A r}^{\mathbf{2}} \mathbf{( \% )}$ \\
\hline $\mathbf{1}$ & 56 & 22 & 22 \\
$\mathbf{2}$ & 50 & 25 & 25 \\
$\mathbf{5}$ & 74 & 13 & 13 \\
$\mathbf{6}$ & $>98$ & $<1$ & $<1$ \\
$\mathbf{7}$ & 64 & 18 & 18 \\
$\mathbf{8}$ & 62 & 19 & 19 \\
$\mathbf{9}$ & 50 & 25 & 25 \\
\hline
\end{tabular}

* Ratios measured by integration of ${ }^{1} \mathrm{H}$ NMR spectra. Equilibration was performed treating the corresponding $\mathrm{PF}_{6}$ salts with 1 equiv. of TMAF in acetonitrile. The solvent was evaporated and the remainder dissolved in $\mathrm{d}_{6}$-benzene ( $60 \mathrm{mM}$ total concentration) for NMR analyses.

steric effects. In contrast, when electron-rich and electron-poor aromatic substituents are present, as in $\mathbf{6 ( F )}$, the unsymmetrically substituted diaryliodonium salt predominates. In the case of ortho-methylation of one of the aryl substituents (as in $\mathbf{7 ( F )}$ and $8(\mathbf{F})$ ), the additional steric demand in the vicinity of iodine shifts the equilibrium toward the unsymmetrically substituted salt, even when other strong electron-donating substituents are on the ring. These observations are consistent with an explanation that invokes steric destabilization of symmetrical diaryliodonium salts bearing ortho-substituents. Also, it should be noted that while compounds 1-8 feature at least one electronrich ring, compound $\mathbf{9}$ does not. Fluoride-promoted ligand exchange is also facile for this salt, demonstrating that this reaction does not require electron-donating substituents on the arenes.

\section{Conclusions}

In conclusion, we have shown that diaryliodonium species undergo fluoride-promoted aryl ligand exchange in acetonitrile and benzene. The data seem to support a mechanism by which a small amount of dissociated "free" fluoride is responsible for catalyzing the aryl ligand exchange among I(III) complexes. Aryl exchange reactions are fast if fluoride is present in nearly stoichiometric amounts, and become precipitously slower as fluoride concentration is diminished. Aryl exchange lowers the apparent regioselectivity of aryl fluoride extrusion from diaryliodonium fluorides under stoichiometric conditions, but this problem disappears at low fluoride ion concentration. The fluoride-promoted aryl exchange reaction is an interesting mechanistic tool for probing relative solution stabilities of various diaryliodonium species directly. It is also possible that this reaction may be useful to prepare novel and currently inaccessible mixed or symmetrically substituted diaryliodonium salts by inducing aryl ligand exchange in solutions containing more easily obtained precursors. The use of such a strategy for diaryliodonium salt synthesis will be reported separately.

\section{Experimental}

\subsection{General experimental procedures}

All reagents were handled under $\mathrm{N}_{2}$. Iodonium salts were shielded from the light during all operations. Acetonitrile (HPLC grade, Aldrich) and $\mathrm{d}_{6}$-acetonitrile were distilled from $\mathrm{P}_{2} \mathrm{O}_{5} \cdot \mathrm{d}_{6}$-Benzene was distilled under $\mathrm{N}_{2}$ from $\mathrm{CaH}_{2}$. THF was distilled under $\mathrm{N}_{2}$ from $\mathrm{Na}$ /benzophenone. Purified solvents were stored under $\mathrm{N}_{2}$ in Schlenk-style, Teflon-capped storage flasks. Tetramethylammonium fluoride (TMAF) (97\%) was obtained from Aldrich Chemical Co. and dried under vacuum at $80^{\circ} \mathrm{C}$ for 3 days prior to use. All other reagents were of analyt- ical grade, from Aldrich Chemical Company. ${ }^{1} \mathrm{H},{ }^{13} \mathrm{C}$ and ${ }^{19} \mathrm{~F}$ NMR spectra were collected and analyzed in the Instrumentation Center at the University of Nebraska-Lincoln. $400 \mathrm{MHz}$ (QNP probe) and $500 \mathrm{MHz}$ (CP TXI Cryoprobe) Bruker NMR spectrometers were used in this study. All NMR experiments were conducted in tubes sealed with PTFE screw cap closures to eliminate loss of volatiles. A Q-TOF I tandem mass spectrometer (Micromass, now Waters) with electrospray ionization was used to analyze the samples. Samples were infused in solution at $5 \mu \mathrm{L} / \mathrm{min}$ by means of a syringe pump. The data were acquired using a mass range of $m / z 100-1500$. The instrument was operated at a mass resolution of 5000 .

\subsection{General procedure for syntheses of diaryliodonium hexafluorophosphates}

\subsubsection{Method A}

In a glove box under $\mathrm{N}_{2}, 1 \mathrm{mmol}$ of the appropriate 1-(diacetoxyiodo)arene (322 $\mathrm{mg}$ for 1, $352 \mathrm{mg}$ for 3, $390 \mathrm{mg}$ for 5, 347 $\mathrm{mg}$ for $\mathbf{6}$, and $350 \mathrm{mg}$ for 8) was weighed into a glass vial and $1.5 \mathrm{~mL}$ of dry acetonitrile was added. A solution of $p$-toluenesulfonic acid monohydrate $(190 \mathrm{mg}, 1 \mathrm{mmol})$ in $1.5 \mathrm{~mL}$ of dry acetonitrile was added by syringe. Upon completion of the addition, anisole (neat, $0.11 \mathrm{~mL}, 1 \mathrm{mmol}$ ) was added and the vial was sealed and taken out of the glove box. The mixture was allowed to stir at room temperature for $2 \mathrm{~h}$. Water $(10 \mathrm{~mL})$ was added and the mixture was transferred to a separatory funnel and extracted $(3 \times 5 \mathrm{~mL})$ with hexanes. The reserved aqueous layer was treated with $502 \mathrm{mg}(3 \mathrm{mmol})$ of $\mathrm{NaPF}_{6}$. The white precipitate was filtered, dried in vacuo, and recrystallized in a mixture of diethyl ether/dichloromethane to give the purified product.

4.2.1.1. Phenyl(4-methoxyphenyl)-iodonium hexafluorophosphate $1\left(\mathrm{PF}_{6}\right)(78 \%)$

$\left[{ }^{1} \mathrm{H}\right] \mathrm{NMR}\left(\mathrm{CD}_{3} \mathrm{CN}, 400 \mathrm{MHz}, 25^{\circ} \mathrm{C}\right): \delta 8.022(\mathrm{~d}, J=7.6 \mathrm{~Hz}, 2 \mathrm{H}$, H-2' / H-6'), 8.011 (d, J = 9.4 Hz, 2H, H-2/H-6), 7.701 (t, J = 7.6 $\left.\mathrm{Hz}, 1 \mathrm{H}, \mathrm{H}-4^{\prime}\right), 7.734\left(\mathrm{t}, J=7.6 \mathrm{~Hz}, 2 \mathrm{H}, \mathrm{H}-3^{\prime} / \mathrm{H}-5^{\prime}\right), 7.063(\mathrm{~d}, J=$ $9.4 \mathrm{~Hz}, 2 \mathrm{H}, \mathrm{H}-3 / \mathrm{H}-5), 3.839$ (s, 6H, OMe); ${ }^{13} \mathrm{C}$ NMR $\left(\mathrm{CD}_{3} \mathrm{CN}\right.$, $\left.100 \mathrm{MHz}, 25{ }^{\circ} \mathrm{C}\right) \delta 164.77$ (C-4), 139.04 (C-2/C-6), 136.22 (C-2' /C-6'), 134.27 (C-4'), 133.77 (C-3' /C-5'), 119.58 (C-3/C-5), 115.29 (C-1'), 102.50 (C-1), 57.09 (OMe); ${ }^{19} \mathrm{~F}$ NMR (CD 3 CN, 376 $\left.\mathrm{MHz}, 25^{\circ} \mathrm{C}\right) \delta-72.754\left(\mathrm{~d}^{1} \mathrm{~J}_{\mathrm{P}-\mathrm{F}}=707.7 \mathrm{~Hz}, \mathrm{PF}_{6}{ }^{-}\right)$; HRMS (HR$\mathrm{FAB})$ : calcd. for $\mathrm{C}_{13} \mathrm{H}_{12} \mathrm{OI}\left[\mathrm{M}-\mathrm{PF}_{6}\right]^{+} 310.9925$; found 310.9932.

4.2.1.2. Bis(4-methoxyphenyl)iodonium hexafluorophosphate $3\left(\mathrm{PF}_{6}\right)(81 \%)$

$\left[{ }^{1} \mathrm{H}\right] \mathrm{NMR}\left(\mathrm{CD}_{3} \mathrm{CN}, 400 \mathrm{MHz}, 25^{\circ} \mathrm{C}\right): \delta 7.973(\mathrm{~d}, J=9.1 \mathrm{~Hz}$, $\left.4 \mathrm{H}, \mathrm{H}-2 / \mathrm{H}^{2} \mathbf{2}^{\prime} / \mathrm{H}-6 / \mathrm{H}^{\prime} 6^{\prime}\right), 7.046\left(\mathrm{~d}, J=9.1 \mathrm{~Hz}, 4 \mathrm{H}, \mathrm{H}-3 / \mathrm{H}-3^{\prime} /\right.$ $\left.\mathrm{H}-5 / \mathrm{H}-5^{\prime}\right), 3.833$ (s, 6H, OMe); ${ }^{3} \mathrm{C}$ NMR $\left(\mathrm{CD}_{3} \mathrm{CN}, 100 \mathrm{MHz}\right.$, $\left.25^{\circ} \mathrm{C}\right) \delta 164.61$ (C-4/C-4'), 138.55 (C-2/C-2' /C-6/C-6'), 119.42 (C-3/C-3' / C-5/C-5'), 103.36 (C-1/C-1'), 57.06 (OMe); ${ }^{19} \mathrm{~F}$ NMR $\left(\mathrm{CD}_{3} \mathrm{CN}, 376 \mathrm{MHz}, 25^{\circ} \mathrm{C}\right) \delta-72.833\left(\mathrm{~d},{ }^{1} J_{\mathrm{P}-\mathrm{F}}=707.3 \mathrm{~Hz}, \mathrm{PF}_{6}{ }^{-}\right)$; HRMS (HRFAB): calcd. for $\mathrm{C}_{14} \mathrm{H}_{14} \mathrm{O}_{2} \mathrm{I}\left[\mathrm{M}-\mathrm{PF}_{6}\right]^{+} 341.0038$; found 341.0036.

4.2.1.3. (3-Trifluoromethylphenyl)(4'-methoxyphenyl)-iodonium hexafluorophosphate $5\left(\mathrm{PF}_{6}\right)(96 \%)$

$\left[{ }^{1} \mathrm{H}\right] \mathrm{NMR}\left(\mathrm{CD}_{3} \mathrm{CN}, 400 \mathrm{MHz}, 25^{\circ} \mathrm{C}\right): \delta 8.384(\mathrm{~s}, 1 \mathrm{H}, \mathrm{H}-2), 8.266$ $(\mathrm{d}, J=8.1 \mathrm{~Hz}, 1 \mathrm{H}, \mathrm{H}-6), 8.056\left(\mathrm{~d}, J=9.2 \mathrm{~Hz}, 2 \mathrm{H}, \mathrm{H}-2^{\prime} / \mathrm{H}-6^{\prime}\right)$, $7.996(\mathrm{~d}, J=8.1 \mathrm{~Hz}, 1 \mathrm{H}, \mathrm{H}-4), 7.716(\mathrm{t}, J=8.1 \mathrm{~Hz}, 1 \mathrm{H}, \mathrm{H}-5)$, $7.083\left(\mathrm{~d}, J=9.2,2 \mathrm{H}, \mathrm{H}-3^{\prime} / \mathrm{H}-5^{\prime}\right), 3.847$ (s, 3H, 4'-OMe); ${ }^{13} \mathrm{C}$ NMR $\left(\mathrm{CD}_{3} \mathrm{CN}, 100 \mathrm{MHz}, 25^{\circ} \mathrm{C}\right) \delta 164.99$ (C-4'), 139.99 (C-6), $139.38\left(\mathrm{C}-2^{\prime} / \mathrm{C}-6^{\prime}\right), 134.44(\mathrm{C}-5), 134.281(\mathrm{q}, J=33.6 \mathrm{~Hz}, \mathrm{C}-3)$, 133.08 (q, $J=3.7 \mathrm{~Hz}, \mathrm{C}-2), 133.05$ (q, $J=3.7 \mathrm{~Hz}, \mathrm{C}-4), 124.11$ (q, $J$ $\left.=272.8 \mathrm{~Hz}, \mathrm{CF}_{3}\right), 119.71\left(\mathrm{C}-3^{\prime} / \mathrm{C}-5^{\prime}\right), 114.83(\mathrm{C}-1), 102.54\left(\mathrm{C}-1^{\prime}\right)$, $57.13\left(4^{\prime}-\mathrm{OMe}\right) ;{ }^{19} \mathrm{~F} \mathrm{NMR}\left(\mathrm{CD}_{3} \mathrm{CN}, 376 \mathrm{MHz}, 25{ }^{\circ} \mathrm{C}\right) \delta-63.420$ $\left({ }^{1} J_{\mathrm{F}-\mathrm{C}}=272.8 \mathrm{~Hz},{ }^{2} J_{\mathrm{F}-\mathrm{C}}=33.6 \mathrm{~Hz}, \mathrm{CF}_{3}\right),-72.625\left(\mathrm{~d},{ }^{1} J_{\mathrm{P}-\mathrm{F}}=707.1\right.$ $\mathrm{Hz}, \mathrm{PF}_{6}{ }^{-}$); HRMS (HRFAB): calcd. for $\mathrm{C}_{14} \mathrm{H}_{11} \mathrm{OIF}_{3}{ }^{\left[\mathrm{M}-\mathrm{PF}_{6}\right]^{+}}$ 378.9807; found 378.9817. 
4.2.1.4. (3-Cyanophenyl)(4'-methoxyphenyl)-iodonium hexafluorophosphate $6\left(\mathrm{PF}_{6}\right)(74 \%)$

$\left[{ }^{1} \mathrm{H}\right] \mathrm{NMR}\left(\mathrm{CD}_{3} \mathrm{CN}, 400 \mathrm{MHz}, 25^{\circ} \mathrm{C}\right): \delta 8.389(\mathrm{t}, J=1.6 \mathrm{~Hz}$, $1 \mathrm{H}, \mathrm{H}-2), 8.273$ (dd, $\left.J_{1}=8.2 \mathrm{~Hz}, J_{2}=1.6 \mathrm{~Hz}, 1 \mathrm{H}, \mathrm{H}-6\right), 8.038$ $\left(\mathrm{d}, J=9.4 \mathrm{~Hz}, 2 \mathrm{H}, \mathrm{H}-2^{\prime} / \mathrm{H}-6^{\prime}\right), 8.017\left(\mathrm{dd}, J_{1}=8.2 \mathrm{~Hz}, J_{2}=1.6\right.$ $\mathrm{Hz}, 1 \mathrm{H}, \mathrm{H}-4), 7.665$ (t, $J=8.2 \mathrm{~Hz}, 1 \mathrm{H}, \mathrm{H}-5), 7.082$ (d, $J=9.4$, 2H, H-3'/H-5'), 3.850 (s, 3H, 4'-OMe); ${ }^{13} \mathrm{C}$ NMR (CD 3 CN, 100 $\left.\mathrm{MHz}, 25^{\circ} \mathrm{C}\right) \delta 165.04$ (C-4'), 140.40 (C-6), 139.50 (C-2), 139.47 (C-2' / C-6'), 137.79 (C-5), 134.13 (C-4), 119.75 (C-3' / C-5'), 117.63 (C-3), $116.75(\mathrm{CN}), 114.53(\mathrm{C}-1), 102.56\left(\mathrm{C}-1^{\prime}\right), 57.16$ (4'-OMe); ${ }^{19} \mathrm{~F}$ NMR $\left(\mathrm{CD}_{3} \mathrm{CN}, 376 \mathrm{MHz}, 25{ }^{\circ} \mathrm{C}\right) \delta-72.675\left(\mathrm{~d},{ }^{1} J_{\mathrm{P}-\mathrm{F}}=707.5\right.$ $\mathrm{Hz}, \mathrm{PF}_{6}^{-}$); HRMS (HRFAB): calcd. for $\mathrm{C}_{14} \mathrm{H}_{11} \mathrm{NOI}\left[\mathrm{M}-\mathrm{PF}_{6}\right]^{+}$ 335.9885; found 335.9876.

\subsubsection{5. (2,5-Dimethylphenyl)(4'-methoxyphenyl)-iodonium} hexafluorophosphate $8\left(\mathrm{PF}_{6}\right)(62 \%)$

$\left[{ }^{1} \mathrm{H}\right] \mathrm{NMR}\left(\mathrm{CD}_{2} \mathrm{Cl}_{2}, 400 \mathrm{MHz}, 25^{\circ} \mathrm{C}\right): \delta 7.88(\mathrm{~d}, J=9.1 \mathrm{~Hz}$, H-2' /H-6', 2H), 7.83 (s, H-6, 1H), 7.41 (s, H-3/H-4, 2H), 7.03 (d, $\left.J=9.1 \mathrm{~Hz}, \mathrm{H}-3^{\prime} / \mathrm{H}-5^{\prime}, 2 \mathrm{H}\right), 3.85$ (s, 4'-OMe, 3H), 2.59 (s, 2-Me, $3 \mathrm{H}), 2.37$ (s, 5-Me, 3H); ${ }^{13} \mathrm{C} \mathrm{NMR}\left(\mathrm{CD}_{2} \mathrm{Cl}_{2}, 100 \mathrm{MHz}, 25{ }^{\circ} \mathrm{C}\right) \delta$ 164.2 (C-4'), 141.7 (C-2), 138.5 (C-5), 137.8 (C-2' / C-6'), 137.1 (C6), 135.4 (C-4), 132.6 (C-3), 119.4 (C-3'/C-5'), 118.0 (C-1), 98.7 (C-1'), 56.5 (4'-OMe), 25.3 (2-Me), 20.9 (5-Me); HRMS (HR$\mathrm{FAB}$ ): calcd. for $\mathrm{C}_{15} \mathrm{H}_{16} \mathrm{OI}\left[\mathrm{M}-\mathrm{PF}_{6}\right]^{+} 339.0246$, 340.0279; found 339.0239, 340.0277.

\subsubsection{Method B}

In a glove box under $\mathrm{N}_{2}$, 1-(diacetoxyiodo)-4-methoxybenzene (352 mg, $1 \mathrm{mmol}$ ) was weighed into a glass vial and $1.5 \mathrm{~mL}$ of dry acetonitrile was added. A solution of $p$-toluenesulfonic acid monohydrate $(190 \mathrm{mg}, 1 \mathrm{mmol})$ in $1.5 \mathrm{~mL}$ of dry acetonitrile was added by syringe. Upon completion of the addition, 1 equiv. of the appropriate tributylstannylarene $(427 \mathrm{mg}$ for 2 , $442 \mathrm{mg}$ for 7) was added and the vial was sealed and taken out of the glove box. The mixture was allowed to stir at room temperature for $2 \mathrm{~h}$. Water $(10 \mathrm{~mL})$ was added and the mixture was transferred to a separatory funnel and extracted $(3 \times$ $5 \mathrm{~mL}$ ) with hexanes. The reserved aqueous layer was treated with $502 \mathrm{mg}$ ( $3 \mathrm{mmol})$ of $\mathrm{NaPF}_{6}$. The white precipitate was filtered, dried in vacuo, and recrystallized in a mixture of diethyl ether/dichloromethane to give the purified product.

\subsubsection{1. (3,4-Dimethoxyphenyl)(4'-methoxyphenyl)-iodonium} hexafluorophosphate $2\left(\mathrm{PF}_{6}\right)(72 \%)$

$\left[{ }^{1} \mathrm{H}\right] \mathrm{NMR}\left(\mathrm{CD}_{3} \mathrm{CN}, 400 \mathrm{MHz}, 25^{\circ} \mathrm{C}\right): \delta 7.986(\mathrm{~d}, J=9.1 \mathrm{~Hz}, 2 \mathrm{H}$, H-2' /H-6'), 7.647 (dd, $\left.J_{1}=8.9 \mathrm{~Hz}, J_{2}=2.2 \mathrm{~Hz}, 1 \mathrm{H}, \mathrm{H}-6\right), 7.558$ $(\mathrm{d}, J=2.2 \mathrm{~Hz}, 1 \mathrm{H}, \mathrm{H}-2), 7.049\left(\mathrm{~d}, J=9.1 \mathrm{~Hz}, 2 \mathrm{H}, \mathrm{H}-3^{\prime} / \mathrm{H}-5^{\prime}\right)$, 7.022 (d, J = 8.9 Hz, 1H, H-5), 3.845 (s, 3H, 3-OMe), 3.843 (s, 3H, 4'-OMe), 3.834 (s, 3H, 4-OMe); ${ }^{13} \mathrm{C}$ NMR $\left(\mathrm{CD}_{3} \mathrm{CN}, 100 \mathrm{MHz}, 25\right.$ $\left.{ }^{\circ} \mathrm{C}\right) \delta 164.58$ (C-4'), 154.62 (C-4), 152.50 (C-3), 138.49 (C-2' /C-6'), 130.65 (C-6), 119.38 (C-2), 119.13 (C-3'/C-5'), 115.52 (C-5), 103.37 (C-1), 102.64 (C-1'), 57.49 (3-OMe), 57.14 (4'-OMe), 57.05 (4-OMe); ${ }^{19} \mathrm{~F}$ NMR $\left(\mathrm{CD}_{3} \mathrm{CN}, 376 \mathrm{MHz}, 25^{\circ} \mathrm{C}\right) \delta-72.786\left(\mathrm{~d},{ }^{1} J_{\mathrm{P}-\mathrm{F}}\right.$ $=705.8 \mathrm{~Hz}, \mathrm{PF}_{6}^{-}$); HRMS (HRFAB): calcd. for $\mathrm{C}_{15} \mathrm{H}_{16} \mathrm{O}_{3} \mathrm{I}[\mathrm{M}-$ $\left.\mathrm{PF}_{6}\right]^{+}$371.0144; found 371.0156.

4.2.2.2. (2-Methyl-4,5-dimethoxyphenyl)(4'-methoxyphenyl)iodonium hexafluorophosphate $7\left(\mathrm{PF}_{6}\right)(75 \%)$

$\left[{ }^{1} \mathrm{H}\right] \mathrm{NMR}\left(\mathrm{CD}_{3} \mathrm{CN}, 400 \mathrm{MHz}, 25^{\circ} \mathrm{C}\right): \delta 7.939(\mathrm{~d}, J=9.2 \mathrm{~Hz}$, 2H, H-2' / H-6'), 7.593 (s, 1H, H-6), 7.055 (d, J = 9.2 Hz, 2H, H-3'/H-5'), 7.026 (s, 1H, H-5), 3.835 (s, 6H, 3/4'-OMe), 3.828 (s, 3H, 4-OMe), 2.550 (s, 3H, 2-Me); ${ }^{13} \mathrm{C} \mathrm{NMR}\left(\mathrm{CD}_{3} \mathrm{CN}, 100\right.$ $\left.\mathrm{MHz}, 25^{\circ} \mathrm{C}\right) \delta 164.45\left(\mathrm{C}-4^{\prime}\right), 154.63$ (C-4), 150.46 (C-5), 138.28 (C-2' / C-6'), 136.71 (C-2), 120.59 (C-6), 119.41 (C-3' /C-5'), 115.28 (C-3), 107.01 (C-1), 102.58 (C-1'), 57.51 (3-OMe), 57.14 (4'OMe), 57.04 (4-OMe); ${ }^{19} \mathrm{~F}$ NMR $\left(\mathrm{CD}_{3} \mathrm{CN}, 376 \mathrm{MHz}, 25^{\circ} \mathrm{C}\right) \delta$ $-72.735\left(\mathrm{~d},{ }^{1} J_{\mathrm{P}-\mathrm{F}}=706.9 \mathrm{~Hz}, \mathrm{PF}_{6}{ }^{-}\right)$; HRMS (HRFAB): calcd. for $\mathrm{C}_{16} \mathrm{H}_{18} \mathrm{O}_{3} \mathrm{I}\left[\mathrm{M}-\mathrm{PF}_{6}\right]^{+}$385.0301; found 385.0313.
4.2.3. Method C

In a glove box under $\mathrm{N}_{2}$, 1-(diacetoxyiodo)-4-bromobenzene (401 mg, $1 \mathrm{mmol}$ ) was weighed into a glass vial and dry acetonitrile $(3 \mathrm{~mL})$ was added. A solution of $p$-toluenesulfonic acid monohydrate $(190 \mathrm{mg}, 1 \mathrm{mmol})$ in $3 \mathrm{~mL}$ of dry acetonitrile was added by syringe. Upon completion of the addition, trimethylstannylbenzene $(240 \mathrm{mg}, 1 \mathrm{mmol})$ was added and the vial was sealed, removed from the glove box, and the mixture was allowed to stir at room temperature for $2 \mathrm{~h}$. Water $(20 \mathrm{~mL})$ was added and the mixture was transferred to a separatory funnel and extracted $(3 \times 5 \mathrm{~mL})$ with hexanes. The reserved aqueous layer was treated with $\mathrm{NaPF}_{6}(502 \mathrm{mg}, 3 \mathrm{mmol})$. The white precipitate was filtered, dried in vacuo, and recrystallized in a mixture of diethyl ether/dichloromethane to give phenyl(4-bromophenyl)-iodonium $\mathbf{9}\left(\mathbf{P F}_{6}\right)(400 \mathrm{mg}, 75 \%) .{ }^{1} \mathrm{H}$ NMR $\left(\mathrm{CD}_{3} \mathrm{CN}, 400 \mathrm{MHz}, 25^{\circ} \mathrm{C}\right): \delta 8.076(\mathrm{~d}, J=7.6 \mathrm{~Hz}, 2 \mathrm{H}$, H-2' / H-6'), 7.954 (d, J = 8.8 Hz, 2H, H-2/H-6), 7.740 (t, J = 7.6 $\left.\mathrm{Hz}, 1 \mathrm{H}, \mathrm{H}-4^{\prime}\right), 7.708$ (d, J = 8.8 Hz, 2H, H-3/H-5), $7.562(\mathrm{t}, J=$ $\left.7.6 \mathrm{~Hz}, 2 \mathrm{H}, \mathrm{H}-3^{\prime} / \mathrm{H}-5^{\prime}\right) ;{ }^{13} \mathrm{C} \mathrm{NMR}\left(\mathrm{CD}_{3} \mathrm{CN}, 100 \mathrm{MHz}, 25^{\circ} \mathrm{C}\right) \delta$ 138.07 (C-2/C-6), 136.60 (C-3/C-5), 136.54 (C-2'/C-6'), 134.35 (C-4'), 133.68 (C-3'/C-5'), 128.89 (C-4), 114.48 (C-1'), 112.27 (C$1) ;{ }^{19} \mathrm{~F}$ NMR $\left(\mathrm{CD}_{3} \mathrm{CN}, 376 \mathrm{MHz}, 25^{\circ} \mathrm{C}\right) \delta-72.851\left(\mathrm{~d},{ }^{1} J_{\mathrm{P}-\mathrm{F}}=\right.$ $706.0 \mathrm{~Hz}, \mathrm{PF}_{6}{ }^{-}$); HRMS (HRFAB): calcd. for $\mathrm{C}_{12} \mathrm{H}_{9} \mathrm{BrI}\left[\mathrm{M}-\mathrm{PF}_{6}\right]^{+}$ 358.8932, 360.8912; found 358.8938, 360.8904.

\subsection{Syntheses of diaryliodonium triflates}

\subsubsection{Phenyl(4-methoxyphenyl)-iodonium triflate 1(OTf)}

To a stirred suspension of diacetoxyiodobenzene $(660 \mathrm{mg}, 2.05$ $\mathrm{mmol}$ ) in $10 \mathrm{~mL}$ dry methylene chloride at $0{ }^{\circ} \mathrm{C}$ under $\mathrm{N}_{2}$, triflic acid $(0.36 \mathrm{~mL}, 4.10 \mathrm{mmol})$ was added dropwise via syringe. The mixture was stirred at $0{ }^{\circ} \mathrm{C}$ for $5 \mathrm{~min}$ and then at room temperature for $1 \mathrm{~h}$. The resulting clear yellow solution was cooled to $0{ }^{\circ} \mathrm{C}$ and anisole $(0.25 \mathrm{~mL}, 2.30 \mathrm{mmol})$ was added dropwise via syringe. The resulting blue colored solution was stirred at 0 ${ }^{\circ} \mathrm{C}$ for $5 \mathrm{~min}$ and then at room temperature for $30 \mathrm{~min}$. The volatiles were removed in vacuo to obtain a dark brown oil which was triturated with diethyl ether. The solvent was removed in vacuo to obtain an off white solid which was triturated with diethyl ether. The solid was collected by filtration and washed with diethyl ether to yield the product $\mathbf{1 ( O T f )}$ as a colorless, fine powdery solid (651 mg, 70.7\%). ${ }^{1} \mathrm{H}$ NMR $\left(500 \mathrm{MHz}, \mathrm{CD}_{3} \mathrm{CN}, 25\right.$ $\left.{ }^{\circ} \mathrm{C}\right): \delta 8.042\left(\mathrm{~d}, J=8.5 \mathrm{~Hz}, 2 \mathrm{H}, \mathrm{H}-2^{\prime} / \mathrm{H}-6^{\prime}\right), 8.017(\mathrm{~d}, J=9.1 \mathrm{~Hz}$, $2 \mathrm{H}, \mathrm{H}-2 / \mathrm{H}-6), 7.690\left(\mathrm{t}, J=7.6 \mathrm{~Hz}, 1 \mathrm{H}, \mathrm{H}-4^{\prime}\right), 7.524(\mathrm{t}, J=8.0 \mathrm{~Hz}$, $\left.2 \mathrm{H}, \mathrm{H}-3^{\prime} / \mathrm{H}-5^{\prime}\right), 7.055(\mathrm{~d}, J=9.1 \mathrm{~Hz}, 2 \mathrm{H}, \mathrm{H}-3 / \mathrm{H}-5), 3.835(\mathrm{~s}, 3 \mathrm{H}$, OMe). ${ }^{13} \mathrm{C}$ NMR (125 MHz, CD 3 CN, $\left.25^{\circ} \mathrm{C}\right): \delta 164.67$ (C-4), 139.02 (C-2/C-6), 136.23 (C-2' /C-6'), 134.14 (C-4'), 133.66 (C-3'/C-5'), $122.37\left(\mathrm{q}, \mathrm{J}_{\mathrm{C}-\mathrm{F}}=320.9 \mathrm{~Hz}, \mathrm{CF}_{3} \mathrm{SO}_{3}{ }^{-}\right), 119.47(\mathrm{C}-3 / \mathrm{C}-5), 115.49(\mathrm{C}-$ $\left.1^{\prime}\right), 102.80$ (C-1), 57.06 (OMe). ${ }^{19} \mathrm{~F}$ NMR (376 MHz, $\mathrm{CD}_{3} \mathrm{CN}, 25$ $\left.{ }^{\circ} \mathrm{C}\right): \delta-79.29\left(\mathrm{~s}, \mathrm{CF}_{3} \mathrm{SO}_{3}{ }^{-}\right)$.

\subsubsection{Bis(4-methoxyphenyl)iodonium triflate 3(OTf)}

In a flame-dried $25 \mathrm{~mL}$ Schlenk flask charged with $\mathrm{N}_{2}$, 1-(diacetoxyiodo)-4-methoxybenzene (753.0 mg, $2.13 \mathrm{mmol}$ ) was dissolved in $7 \mathrm{~mL}$ dry methylene chloride. With stirring, anisole $(0.93 \mathrm{~mL}, 8.52 \mathrm{mmol})$ was added by syringe. The solution was cooled to $-10{ }^{\circ} \mathrm{C}$ in a sodium chloride-ice bath. To this solution, triflic acid $(0.21 \mathrm{~mL}, 2.34 \mathrm{mmol})$ was added dropwise over the course of $10 \mathrm{~min}$ by syringe. A deep blue color was immediately observed upon addition. After addition, the solution was allowed to warm slowly to room temperature overnight. The volatiles were removed in vacuo to obtain a crude solid. The solid was redissolved in methylene chloride and precipitated with a $10 \%$ solution of ether in hexanes to yield bis(4-methoxyphenyl)iodonium triflate as a colorless solid (729.6 mg, 69.5\%). ${ }^{1} \mathrm{H}$ NMR (400 MHz, $\left.\mathrm{CD}_{3} \mathrm{CN}, 25^{\circ} \mathrm{C}\right)$ : $\delta 7.981\left(\mathrm{~d}, J=8.8 \mathrm{~Hz}, 2 \mathrm{H}, \mathrm{H}-2 / \mathrm{H}-2^{\prime} / \mathrm{H}-6 / \mathrm{H}-6^{\prime}\right), 7.038(\mathrm{~d}, J=$ $\left.8.8 \mathrm{~Hz}, 2 \mathrm{H}, \mathrm{H}-3 / \mathrm{H}_{-3} \mathrm{3}^{\prime} \mathrm{H}-5 / \mathrm{H}-5^{\prime}\right), 3.829$ (s, 3H, OMe). ${ }^{13} \mathrm{C}$ NMR $\left(100 \mathrm{MHz}, \mathrm{CD}_{3} \mathrm{CN}, 25^{\circ} \mathrm{C}\right): \delta 164.258\left(\mathrm{C}-4 / \mathrm{C}-4^{\prime}\right), 138.280(\mathrm{C}-2 /$ 
C-2'/C-6/C-6'), 122.148 (q, $\left.J=320.8 \mathrm{~Hz}, \mathrm{CF}_{3} \mathrm{SO}_{3}^{-}{ }^{-}\right), 119.066$ (C-3/C-3'/C-5/C-5'), 103.383 (C-1/C-1'), 56.772 (OMe). ${ }^{19} \mathrm{~F}$ $\mathrm{NMR}\left(376 \mathrm{MHz}, \mathrm{CD}_{3} \mathrm{CN}, 25^{\circ} \mathrm{C}\right): \delta-79.249\left(\mathrm{~s}, \mathrm{CF}_{3} \mathrm{SO}_{3}{ }^{-}\right)$.

\subsubsection{Diphenyliodonium triflate 4(OTf)}

To a stirred suspension of diacetoxyiodobenzene $(660 \mathrm{mg}$, $2.05 \mathrm{mmol}$ ) in $10 \mathrm{~mL}$ dry methylene chloride at $0{ }^{\circ} \mathrm{C}$ under $\mathrm{N}_{2}$, triflic acid $(0.36 \mathrm{~mL}, 4.10 \mathrm{mmol})$ was added dropwise via syringe. The mixture was stirred at $0{ }^{\circ} \mathrm{C}$ for $5 \mathrm{~min}$ and then at room temperature for $1 \mathrm{~h}$. The resulting clear yellow solution was cooled to $0{ }^{\circ} \mathrm{C}$ and benzene $(0.37 \mathrm{~mL}, 4.10 \mathrm{mmol})$ was added dropwise via syringe. The resulting solution was stirred at $0{ }^{\circ} \mathrm{C}$ for $5 \mathrm{~min}$ and then at room temperature for $30 \mathrm{~min}$. The volatiles were removed in vacuo to obtain a crude brown solid which was triturated with diethyl ether. The solid was collected by filtration and washed with diethyl ether to yield the product 4 (OTf) as a light brown flaky crystalline solid (726 $\mathrm{mg}, 82.4 \%) .{ }^{1} \mathrm{H}$ NMR $\left(500 \mathrm{MHz}, \mathrm{CD}_{3} \mathrm{CN}, 25^{\circ} \mathrm{C}\right): \delta 8.091$ (d, J $\left.=8.2 \mathrm{~Hz}, 4 \mathrm{H}, \mathrm{H}-2 / \mathrm{H}-2^{\prime} / \mathrm{H}-6 / \mathrm{H}-6^{\prime}\right), 7.710(\mathrm{t}, J=7.6 \mathrm{~Hz}, 2 \mathrm{H}$, $\left.\mathrm{H}-4 / \mathrm{H}-4^{\prime}\right), 7.540\left(\mathrm{t}, J=7.9 \mathrm{~Hz}, 4 \mathrm{H}, \mathrm{H}-3 / \mathrm{H}-3^{\prime} / \mathrm{H}-5 / \mathrm{H}-5^{\prime}\right) .{ }^{13} \mathrm{C}$ NMR (125 MHz, CD 3 CN, $\left.25^{\circ} \mathrm{C}\right): \delta 136.75$ (C-2/C-2'/C-6/C-6'), 134.33 (C-4/C-4'), 133.76 (C-3/C-3'/C-5/C-5'), 122.34 (q, J $\left.=321.0 \mathrm{~Hz}, \mathrm{CF}_{3} \mathrm{SO}_{3}^{-}\right), 114.84\left(\mathrm{C}-1 / \mathrm{C}-1^{\prime}\right) .{ }^{19} \mathrm{~F}$ NMR $(376 \mathrm{MHz}$, $\left.\mathrm{CD}_{3} \mathrm{CN}, 25^{\circ} \mathrm{C}\right): \delta-79.33\left(\mathrm{~s}, \mathrm{CF}_{3} \mathrm{SO}_{3}^{-}\right)$.

\subsection{Syntheses of bis(4-methoxyphenyl)iodonium fluoride 4(F) and diphenyliodonium fluoride 3(F)}

In a $\mathrm{N}_{2}$ charged glove box, a mixture of $454 \mathrm{mg}(1 \mathrm{mmol})$ bis(4methoxyphenyl)-iodonium trifluoroacetate and $262 \mathrm{mg}$ (1 $\mathrm{mmol}$ ) anhydrous tetrabutylammonium fluoride (TBAF) was treated with $1 \mathrm{~mL}$ of dry THF. The solution was allowed to stand for $1 \mathrm{~h}$, the white precipitate was collected and washed (3× $0.5 \mathrm{~mL}$ ) with THF. Calculated yield: $288.7 \mathrm{mg}(80.2 \%) .{ }^{1} \mathrm{H}$ NMR (saturated solution in $\mathrm{CD}_{3} \mathrm{CN}, 400 \mathrm{MHz}, 25^{\circ} \mathrm{C}$ ): $\delta 7.739$ $\left(\mathrm{d}, J=8.9 \mathrm{~Hz}, 4 \mathrm{H}, \mathrm{H}-2 / \mathrm{H}-2^{\prime} / \mathrm{H}-6 / \mathrm{H}-6^{\prime}\right), 6.853(\mathrm{~d}, J=8.9 \mathrm{~Hz}, 4 \mathrm{H}$, H-3/H-3'/H-5/H-5'), 3.769 (s, 6H, OMe); ${ }^{13} \mathrm{C}$ NMR $\left(\mathrm{CD}_{3} \mathrm{CN}, 100\right.$ MHz, $\left.25^{\circ} \mathrm{C}\right) \delta 162.43$ (C-4/C-4'), 136.98 (C-2/C-2'/C-6/C-6'), 117.52 (C-3/C-3'/C-5/C-5'), 113.20 (C-1/C-1'), 56.55 (OMe); ${ }^{19} \mathrm{~F}$ $\operatorname{NMR}\left(\mathrm{CD}_{3} \mathrm{CN}, 376 \mathrm{MHz}, 25^{\circ} \mathrm{C}\right) \delta-17.9$ (broad s, I-F).

Diphenyliodonium fluoride 4(F) was prepared from commercially available diphenyliodonium nitrate and TBAF by the same procedure in $70 \%$ yield. ${ }^{1} \mathrm{H}$ NMR (saturated solution in $\left.\mathrm{CD}_{3} \mathrm{CN}, 400 \mathrm{MHz}, 25^{\circ} \mathrm{C}\right): \delta 7.819(\mathrm{~d}, J=7.5 \mathrm{~Hz}, 4 \mathrm{H}, \mathrm{H}-2 / \mathrm{H}-$ $\left.2^{\prime} / \mathrm{H}-6 / \mathrm{H}-6^{\prime}\right), 7.457\left(\mathrm{t}, J=7.5 \mathrm{~Hz}, 2 \mathrm{H}, \mathrm{H}-4 / \mathrm{H}-4^{\prime}\right), 7.299(\mathrm{t}, J=7.5$ $\left.\mathrm{Hz}, 4 \mathrm{H}, \mathrm{H}-3 / \mathrm{H}-3^{\prime} / \mathrm{H}-5 / \mathrm{H}-5^{\prime}\right) ;{ }^{13} \mathrm{C}$ NMR $\left(\mathrm{CD}_{3} \mathrm{CN}, 100 \mathrm{MHz}, 25\right.$ $\left.{ }^{\circ} \mathrm{C}\right) \delta 135.29$ (C-2/C-2'/C-6/C-6), 131.62 (C-3/C-3'/C-5/C-5'), 131.21 (C-4/C-4'), 122.91 (C-1/C-1'); ${ }^{19} \mathrm{~F}$ NMR $\left(\mathrm{CD}_{3} \mathrm{CN}, 376\right.$ $\mathrm{MHz}, 25^{\circ} \mathrm{C}$ ) $\delta-13.0$ (broad s, I-F).

\subsection{Swapping reaction in acetonitrile}

To a solution of the appropriate diaryliodonium hexafluorophosphate $\left(0.05 \mathrm{mmol}\right.$ in $0.3 \mathrm{~mL}$ of $\mathrm{d}_{3}$-acetonitrile) was slowly added a solution of TMAF $(0.05 \mathrm{mmol})$ in $\mathrm{d}_{3}$-acetonitile (amount varied). The resulting solution was mixed well and transferred into an NMR tube equipped with a Teflon screw cap closure. The progress of the reaction was monitored by ${ }^{1} \mathrm{H}$ NMR spectroscopy; rates were back calculated based upon the deconvoluted peak areas.

Acknowledgments - We thank the National Science Foundation (CHE 0717562) for support and the National Institutes of Health (RR016544-01) for infrastructure to conduct this research.

\section{References}

[1] F. Dollé, D. Roeda, B. Kuhnast and M.-C. Lasne. Fluor. Health, (2008), pp. 3-65.

[2] H.J. Wester. Handb. Nucl. Chem., 4 (2003), pp. 167-209.
[3] O. Couturier, A. Luxen, J.-F. Chatal, J.-P. Vuillez, P. Rigo and R. Hustinx. Eur. J. Nucl. Med. Mol. Imaging, 31 (2004), pp. 1182-1206.

[4] C. Lemaire, S. Gillet, S. Guillouet, A. Plenevaux, J. Aerts and A. Luxen. Eur. J. Org. Chem., (2004), pp. 2899-2904.

[5] M.A. Carroll, J. Nairne and J.L. Woodcraft. J. Labelled Compd. Radiopharm., 50 (2007), pp. 452-454.

[6] R.N. Krasikova, O.F. Kuznetsova, O.S. Fedorova, I.K. Mosevich, V.I. Maleev, Y.N. Belokon, T.F. Savel'eva, A.S. Sagiyan, S.A. Dadayan and A.A. Petrosyan. Radiochemistry (New York, NY), 49 (2007), pp. 512-518.

[7] H. Sun and S.G. DiMagno. Chem. Commun., (2007), pp. 528-529.

[8] H. Sun and S.G. DiMagno. J. Fluor. Chem., 128 (2007), pp. 806-812.

[9] V.W. Pike, J.-H. Chun, F.G. Simeon, S. Lu and Y.-S. Lee, 236th ACS National Meeting Abstracts of PapersPhiladelphia, PA, United States, August 17-21 (2008) INOR-296.

[10] V.W. Pike. Trends Pharmacol. Sci., 30 (2009), pp. 431-440.

[11] V.W. Pike and F.I. Aigbirhio. J. Chem. Soc., Chem. Commun., (1995), pp. 2215-2216.

[12] F.M. Beringer and R.A. Nathan. J. Org. Chem., 35 (1970), pp. 2095-2096.

[13] G.F. Koser, R.H. Wettach and C.S. Smith. J. Org. Chem., 45 (1980), pp. 1543-1544.

[14] M. Ochiai, Y. Kitagawa, N. Takayama, Y. Takaoka and M. Shiro. J. Am. Chem. Soc., 121 (1999), pp. 9233-9234.

[15] M. Ochiai, M. Toyonari, T. Sueda and Y. Kitagawa. Tetrahedron Lett., 37 (1996), pp. 8421-8424.

[16] V.W. Pike, F. Butt, A. Shah and D.A. Widdowson. J. Chem. Soc., Perkin Trans., 1 (1999), pp. 245-248.

[17] P.J. Stang, R. Tykwinski and V. Zhdankin. J. Heterocycl. Chem., 29 (1992), pp. 815-818.

[18] N.S. Zefirov, S.O. Safronov, A.A. Kaznacheev and V.V. Zhdankin. Z. Org. Chim., 25 (1989), pp. 1807-1808.

[19] F.M. Beringer and L.L. Chang. J. Org. Chem., 37 (1972), pp. 1516-1519.

[20] M.A. Carroll, V.W. Pike and D.A. Widdowson. Tetrahedron Lett., 41 (2000), pp. 5393-5396.

[21] F.M. Beringer, A. Brierley, M. Drexler, E.M. Gindler and C.C. Lumpkin. J. Am. Chem. Soc., 75 (1953), pp. 2708-2712.

[22] F.M. Beringer, W.J. Daniel, S.A. Galton and G. Rubin. J. Org. Chem., 31 (1966), pp. 4315-4318.

[23] F.M. Beringer and P.S. Forgione. Tetrahedron, 19 (1963), pp. 739-748.

[24] F.M. Beringer, J.W. Dehn and M. Winicov. J. Am. Chem. Soc., 82 (1960), pp. 2948-2952.

[25] F.M. Beringer and R.A. Falk. J. Chem. Soc., (1964), pp. 4442-4451.

[26] A. Krief, W. Dumont and M. Robert. Chem. Commun., (2005), pp. 2167-2168.

[27] A. Krief, W. Dumont and M. Robert. Synlett, (2006), pp. 2601-2604.

[28] Y. Yamada and M. Okawara. Bull. Chem. Soc. Jpn., 45 (1972), pp. 2515-2519.

[29] J.J. Lubinkowski, M. Gomez, J.L. Calderon and W.E. McEwen. J. Org. Chem., 43 (1978), pp. 2432-2435.

[30] F.M. Beringer, E.M. Gindler, M. Rapoport and R.J. Taylor. J. Am. Chem. Soc., 81 (1959), pp. 351-361.

[31] S.-K. Kang, H.-W. Lee, S.-B. Jang and P.-S. Ho. J. Org. Chem., 61 (1996), pp. 4720-4724.

[32] R.A. Scherrer and H.R. Beatty. J. Org. Chem., 45 (1980), pp. 2127-2131.

[33] A.J. Canty, T. Rodemann and J.H. Ryan. Adv. Organomet. Chem., 55 (2008), pp. 279-313.

[34] M. Uchiyama, T. Suzuki and Y. Yamazaki. Chem. Lett., (1983), pp. $1165-1166$.

[35] O.A. Reutov, G.A. Ertel and O.A. Ptitsina. Dokl. Akad. Nauk SSSR, 133 (1960), pp. 1108-1110.

[36] H.J. Reich and C.S. Cooperman. J. Am. Chem. Soc., 95 (1973), pp. 5077-5078.

[37] F.M. Beringer, R.A. Falk, M. Karniol, I. Lillien, G. Masulio, M. Mausner and E. Sommer. J. Am. Chem. Soc., 81 (1959), pp. 342-351.

[38] T. Kitamura, J. Matsuyuki and H. Taniguchi. Synthesis, (1994), pp. 147-148.

[39] A. Shah, V.W. Pike and D.A. Widdowson. J. Chem. Soc., Perkin Trans., 1 (1997), pp. 2463-2465.

[40] B. Wang, J.W. Graskemper, L. Qin and S.G. DiMagno. Angew. Chem., (2010).

[41] M.C. Caserio, D.L. Glusker and J.D. Roberts. J. Am. Chem. Soc., 81 (1959), pp. 336-342.

[42] M.-R. Zhang, K. Kumata and K. Suzuki. Tetrahedron Lett., 48 (2007), pp. 8632-8635. 